\title{
REVIEW
}

\section{Genetic and epigenetic insights into fetal alcohol spectrum disorders}

\author{
Michèle Ramsay*
}

\begin{abstract}
The magnitude of the detrimental effects following in utero alcohol exposure, including fetal alcohol syndrome and other fetal alcohol spectrum disorders (FASD), is globally underestimated. The effects include irreversible cognitive and behavioral disabilities as a result of abnormal brain development, pre- and postnatal growth retardation and facial dysmorphism. Parental alcohol exposure and its effect on offspring has been recognized for centuries, but only recently have we begun to gain molecular insight into the mechanisms involved in alcohol teratogenesis. Genetic attributes (susceptibility and protective alleles) of the mother and the fetus contribute to the risk of developing FASD and specific additional environmental conditions, including malnutrition, have an important role. The severity of FASD depends on the level of alcohol exposure, the developmental stage at which exposure occurs and the nature of the exposure (chronic or acute), and although the most vulnerable period is during the first trimester, damage can occur throughout gestation. Preconception alcohol exposure can also have a detrimental effect on the offspring. Several developmental pathways are affected in FASD, including nervous system development, growth and remodeling of tissues, as well as metabolic pathways that regulate glucocorticoid signaling and balanced levels of retinol, insulin and nitric oxide. A body of knowledge has accumulated to support the role of environmentally induced epigenetic remodeling during gametogenesis and after conception as a key mechanism for the teratogenic effects of FASD that persist into adulthood. Transgenerational effects are likely to contribute to the global burden of alcohol-related disease. FASD results in lifelong disability and preventative programs should include both maternal alcohol abstention and preconception alcohol avoidance.
\end{abstract}

\section{The public health impact of fetal alcohol spectrum disorders is underestimated}

Fetal alcohol spectrum disorders (FASD) are characterized by a continuum of structural and neurodevelopmental anomalies following a history of in utero alcohol exposure. Clinical diagnostic guidelines have been developed to aid accurate diagnosis [1-3] and to differentiate between fetal alcohol syndrome (FAS) at the most severe end of the spectrum, and partial fetal alcohol syndrome, alcohol-related birth defects and alcoholrelated neurodevelopmental disorder. FAS manifests with a set of characteristics, including craniofacial dysmorphology (such as a thin upper lip, smooth philtrum and small eye openings), pre- and postnatal growth retardation, and abnormal growth and development of the central nervous system, resulting in lifelong mental,

*Correspondence: Michele.ramsay@nhls.ac.za

Division of Human Genetics, National Health Laboratory Service and School of Pathology, University of the Witwatersrand, Johannesburg, 2000, South Africa cognitive and behavioral disabilities. FASD is the commonest preventable cause of mental disability. In most countries the prevalence of FAS ranges between 0.5 and 2.0 per 1,000 live births [4], but it is strikingly higher in some communities. In South Africa, a prevalence as high as 65.2 per 1,000 children of school-going age was reported in a mixed ancestry community in the Western Cape [5] and 67.2 per 1,000 children in similar communities in the Northern Cape Province [6].

The global burden of alcohol-related disease accounted for $4 \%$ of all disability-adjusted life years as reported in 2004, with striking regional differences [7], up from 3.5\% in 1990. Although it is estimated that only between $5 \%$ and $10 \%$ of offspring exposed in utero are likely to have alcohol-related deficits [8], this is probably an underestimate [9]. It is possible that many idiopathic neurodevelopmental disorders, including some cases of autism and attention deficit hyperactivity disorder (ADHD), may also be attributable to transgenerational effects of alcohol exposure. In the USA, it is estimated that FASD may affect up to $1 \%$ of the population [10] and incur considerable costs [11], but the prevalence, especially in 
middle to low income countries, may be considerably higher than reported estimates $[12,13]$.

\section{Lessons from early studies in humans and in animal models}

The deleterious effects of parental alcohol use on their offspring have been recognized and documented for centuries, including observations during the 'gin epidemic' in England (1720 to 1750) and reports during the 19th and early 20th centuries (summarized by Warner and Rosett [14]). The term fetal alcohol syndrome (FAS) and the formal medical description is as recent as 1973 [15].

Many animal studies have shown that clinical severity following in utero ethanol exposure correlates with the developmental stage (timing), the dose and the frequency of exposure (chronic versus acute) [16,17]; it is the result of complex gene-environment interactions that alter gene expression patterns, especially during development. The first trimester is considered the most vulnerable period, but fetal damage occurs throughout gestation. Rodent models have been used most often (especially the mouse and rat) and various regimens of alcohol administration have resulted in remarkable phenotypic similarities with the features of FASD in humans, including distinctive craniofacial alterations, stunted growth and behavioral abnormalities. What has become clear, however, as demonstrated by crosses between inbred mouse strains that were similarly exposed to alcohol, is that the parental genomic contributions to the fetus are important in attributing risk.

\section{The role of genetic variation in FASD remains poorly understood}

There is no question that genetic variation has a role in susceptibility to adverse effects following in utero alcohol exposure. The question is, therefore, what is the nature and magnitude of the genetic effect and how does genetic variation interact with environmental factors (for example, nutrition and environmentally induced epigenetic remodeling) to cause teratogenic effects. Many studies in rodent models have indicated that genetic background is crucial in understanding risk, as there are recognized susceptible inbred mouse strains and other inbred strains that remain unaffected despite similar exposure to ethanol [18-20]. Differences among these strains relate to alcohol preference, alcohol metabolism and behavior. For example, mouse studies demonstrated an inverse relationship between maternal alcohol dehydrogenase activity and maternal blood alcohol levels and consequent fetal abnormalities, but suggested that other inherited factors from both the mother and the fetus were also important [19,21-23].

In contrast, relatively few studies have investigated the role of genetic variation in humans in determining predisposition and clinical severity. It has, however, been documented that siblings of FAS children have a dramatically increased risk for FAS (170 per 1,000 among older sibs and 771 per 1,000 in younger sibs compared with 1.9 per 1,000 in the population studied as a whole) and there is higher concordance between monozygotic twins than between dizygotic twins [24,25]. Genetic studies have primarily explored the role of alcohol-metabolizing enzymes, including alcohol dehydrogenases $(A D H)$, aldehyde dehydrogenases $(A L D H)$ and cytochrome P450 2E1 (CYP2E1), in the mothers and their FAS offspring; these studies have used relatively small sample sizes $[26,27]$. Functionally significant nonsynonymous variants at the $A D H 1 B$ locus $(A D H 1 B * 2$ and $\left.A D H 1 B^{*} 3\right)$, which result in faster and more efficient ethanol clearance, have been associated with a mild protective effect in case-control and cohort studies in several populations, including African Americans $[28,29]$ and South Africans of mixed ancestry [30], although in association with different alleles $[26,27,31]$. The mode of action is unclear but a recent study in a large European population demonstrated a strong association between one of these $A D H 1 B$ non-synonymous variant alleles $(A D H 1 B * 2$; rs1229984) and lower alcohol consumption before and during pregnancy [32]. Excessive alcohol exposure can induce CYP2E1 expression, another route for alcohol metabolism. Some CYP2E1 allelic variants are associated with enhanced metabolic capacity and may modulate the risk for FAS. Furthermore, CYP2E1 is expressed in the placenta, fetal liver and fetal brain during organogenesis, where the CYP2E1-catalyzed oxidation of ethanol may cause oxidative stress (reviewed in Gemma et al. [27]). No genome-wide association studies have been done for FAS or FASD, probably because of the recognition of multiple common environmental risk factors that are difficult to quantify and a paucity of large sample sizes and appropriate controls.

\section{The impact of alcohol on biological pathways and the mechanisms of teratogenesis}

Efforts to understand the effects of alcohol exposure on the adult and developing brain, as well as other physiological impacts, have led to a vast literature describing the effects of alcohol on cells, organs and organisms (reviewed in [33-35]). Genetic contributions to predisposition have been explored to a limited extent, but important insight has come from investigating gene expression, biochemical markers and physiological effects of pre- and postnatal alcohol exposure. These are mediated through pathogenic mechanisms that involve many pathways that have been extensively studied in the liver (the main site of ethanol metabolism and its toxic metabolites, including acetaldehyde) and the nervous system (including the brain). The origins and mechanisms 
Table 1. Global gene expression studies after in utero alcohol exposure in mouse models

\begin{tabular}{|c|c|c|c|c|c|}
\hline Alcohol exposure* & Tissue & $\begin{array}{l}\text { Key upregulated } \\
\text { genes/pathways }\end{array}$ & $\begin{array}{l}\text { Key downregulated } \\
\text { genes/pathways }\end{array}$ & $\begin{array}{l}\text { Functional } \\
\text { pathway }\end{array}$ & References \\
\hline $\begin{array}{l}\text { GD7-9 } \\
\text { (daily intraperitoneal } \\
\text { dose } 2.9 \mathrm{~g} / \mathrm{kg} \text { ) }\end{array}$ & Fetal brain & & $\begin{array}{l}\text { Timp4, Bmp15, Rnf25, Tulp4 and } \\
\text { Dexras } 1\end{array}$ & $\begin{array}{l}\text { Cell proliferation, cell } \\
\text { differentiation and apoptosis; } \\
\text { affecting tissue growth and } \\
\text { remodeling and neural growth } \\
\text { and survival }\end{array}$ & {$[37]$} \\
\hline $\begin{array}{l}\text { GD8 } \\
(2 \text { doses, } 4 \mathrm{~h} \text { apart, } \\
2.9 \mathrm{~g} / \mathrm{kg})\end{array}$ & $\begin{array}{l}\text { Head fold, } 3 \mathrm{~h} \\
\text { after alcohol } \\
\text { exposure }\end{array}$ & $\begin{array}{l}\text { B6 } \mathrm{N}^{+} \text {: glycolysis and } \\
\text { pentose phosphate } \\
\text { pathway; } \mathrm{B}^{+} \mathrm{J}^{+} \text {and } \mathrm{B} 6 \mathrm{~N}^{+} \text {: } \\
\text { tight junction, focal } \\
\text { adhesion, adherens junction } \\
\text { and regulation of the } \\
\text { actin cytoskeleton }\end{array}$ & $\begin{array}{l}\text { B6 } \mathrm{N}^{\dagger} \text { : ribosomal proteins } \\
\text { and proteasome; } \mathrm{B}^{+} \mathrm{J}^{+} \text {: none } \\
\text { detected }\end{array}$ & $\begin{array}{l}\text { Common signaling pathways } \\
\text { linking receptor activation to } \\
\text { cytoskeletal reorganization }\end{array}$ & {$[40]$} \\
\hline $\begin{array}{l}\text { GD } 8.25 \\
\text { for } 46 \mathrm{~h} \text { (peak } \\
\text { alcohol concentration } \\
88 \mathrm{mM} \text { ) }\end{array}$ & $\begin{array}{l}\text { Whole embryo } \\
\text { culture }\end{array}$ & $\begin{array}{l}\text { All } 3^{\prime} \text { miRNA motifs } \\
\text { showed upregulatory } \\
\text { effects }^{\ddagger}\end{array}$ & $\begin{array}{l}\text { Most } 5 \text { ' cis-acting regulatory } \\
\text { motifs (transcription binding } \\
\text { sites) showed down regulatory } \\
\text { effects }\end{array}$ & $\begin{array}{l}\text { Developmental deficit of } \\
\text { growth, neuronal axis and } \\
\text { neural patterning, } \\
\text { hemopoiesis and apoptosis }\end{array}$ & {$[41]$} \\
\hline $\begin{array}{l}\text { GD } 8.25 \\
\text { for } 46 \mathrm{~h} \text { (peak } \\
\text { alcohol concentration } \\
88 \mathrm{mM} \text { ) }\end{array}$ & $\begin{array}{l}\text { Whole embryo } \\
\text { culture }\end{array}$ & $\begin{array}{l}\text { Decreased methylation: } \\
\text { Nlgn3, Elav12, Sox 21, Sim1, } \\
\text { Igf2r and Histh3d }\end{array}$ & $\begin{array}{l}\text { Increased methylation: } \\
\text { Cyp } 4 f 13\end{array}$ & $\begin{array}{l}\text { Metabolism (Cyp4f13); } \\
\text { imprinting (lgf2r); chromatin } \\
\text { (Histh3d); and development } \\
\text { (other genes) }\end{array}$ & {$[38]$} \\
\hline GD0.5-8.5 & $\begin{array}{l}\text { Liver from } \\
\text { 28-day-old males }\end{array}$ & $\begin{array}{l}\text { D14ertd449e, Ly6e } \\
\text { and Rrm2 }\end{array}$ & $\begin{array}{l}\text { Lima1, Socs2, Cables1 } \\
\text { and Vidir }\end{array}$ & $\begin{array}{l}\text { Growth; nervous system } \\
\text { development }\end{array}$ & {$[39]$} \\
\hline
\end{tabular}

${ }^{*} \mathrm{GD}$, gestational day. ${ }^{\dagger} \mathrm{C} 57 \mathrm{BL} / 6$ substrains: B6J embryos had a higher incidence of FASD features than B6N. ${ }^{\ddagger} \mathrm{A}$ possible interpretation is that many highly expressed genes were not appropriately downregulated because of delayed expression of miRNAs that would normally reduce expression.

of craniofacial dysmorphism following fetal exposure have been examined and compounds that exacerbate or ameliorate the teratogenic effects of alcohol have been shown to include antioxidants, sonic hedgehog protein and retinoids (summarized by Sulik [36]).

Common functional deficits following in utero alcohol exposure in mouse and rat models include cell proliferation, differentiation and apoptosis, affecting tissue growth and remodeling and specifically neuronal growth and survival. Preliminary global gene expression studies have corroborated some of these findings and have revealed the involvement of groups of genes related through function or common pathways. Each experimental design was different, making it difficult to compare the studies, but the main conclusions are summarized in Table 1 [37-41].

Bioinformatic analyses of gene expression microarray data from fetuses exposed and unexposed to alcohol have examined upstream regulatory regions for common transcription binding sites and 5' untranslated regions for potential microRNA (miRNA) binding sites for differentially expressed genes. The results suggest that alterations in miRNA functions may have a role in alcohol-related teratogenicity [41]. In addition, fetal alcohol exposure was shown to alter common signaling pathways linking receptor activation to cytoskeletal reorganization, causing altered cell motility and mobility as well as metabolic capacity [40]. More focused rodent gene expression studies have explored central nervous system development and neuronal migration, glucocorticoid signaling, and nitric oxide, insulin and retinol levels following in utero alcohol exposure (for example, [42-44]).

Gene expression is known to be altered by DNA methylation status and by chromatin remodeling following histone modification, including methylation, acetylation and phosphorylation. Given that abnormal neuronal development and neurodegeneration are characteristics of FASD and alcoholism, it is important to understand how these molecular processes are altered in affected tissues. Particular emphasis has been placed on understanding the effect of alcohol on the methyl donor pathway, including $S$-adenosylmethionine (a methyl donor) and the DNA methyltransferases $[45,46]$. One of the early studies demonstrated that acute alcohol exposure in pregnant mice (from gestation day 9 to 11) resulted in reduced methylation of fetal DNA and levels of DNA methyltransferase [47]. Another study in male rats showed significantly decreased cytosine methyltransferase (Dnmt1) mRNA levels in their sperm, suggesting that this may be one of the mechanisms leading to altered gene expression levels after conception [48]. Ethanol has also been demonstrated to be associated with post-translational histone modification in a rat model [49-51]. Significant changes in DNA methylation were observed during early embryonic development of the nervous system involving genes known to have a role in the cell cycle, growth and apoptosis, with increased 
methylation in some genes and decreased methylation in others [38].

\section{Epigenetic remodeling and vulnerability to the teratogenic effects of alcohol: preconception, early development and transgenerational effects}

In 1920 Lord D'Abernon set the scene by writing in the preface to the second edition of Alcohol: Its Action on the Organism [52] a list of research questions that should receive priority, including: 'Does parental alcoholism affect injuriously the health and development of offspring, and if so, are the resultant conditions transmissible to subsequent generations?'

The previous section provided some evidence supporting the involvement of epigenetic remodeling in alcohol teratogenesis, and this hypothesis is further summarized in a recent review supporting an epigenetic dimension as one of the key molecular mechanisms in FASD [53]. During development there are essentially three main stages of generalized global epigenetic remodeling: first, during gametogenesis, when there is a wave of demethylation followed by sex-specific genetic imprinting and generalized methylation; second, during preimplantation, which is characterized by generalized DNA demethylation in the zygote (with the exception of imprinted loci); and third, another wave of de novo methylation during gastrulation [54]. Each of these stages therefore characterizes a time of particular vulnerability for the disruption of normal epigenetic signals and the adverse effects of alcohol exposure. There is ample evidence to suggest that epigenetic perturbations are subtle and not all-or-nothing responses, resulting in shifts towards increased or decreased gene expression, a phenomenon that would be in line with the broad range of clinical manifestations reflecting a dynamic and individual response to alcohol exposure.

The consequences of epigenetic remodeling can be studied at a genomic level [55] but to thoroughly explore cause and effect would require additional biochemical and proteomic studies to understand the complex, interrelated molecular underpinnings of alcohol effects in FASD. Several reviews have documented the teratogenic effects of alcohol in animal models [56,57]. Below I summarize current knowledge regarding the effects of alcohol exposure from the preconception stage to preimplantation and gastrulation on fetal and postnatal development. The evidence for transgenerational effects of environmental alcohol exposure is briefly summarized.

Despite an emphasis on maternal alcohol consumption as the major driver of fetal alcohol effects, the role of alcohol in the preconception period in men and its effect on their offspring, even in the absence of gestational alcohol exposure, has long been recognized [58]. The deleterious effects of paternal preconception alcohol exposure have now been well documented in humans and include reduced birth weight and impaired cognitive functioning [59,60]; however, the mechanisms remain poorly understood. In an attempt to establish a link between alcohol consumption in men and epigenetic changes in sperm DNA, paternally imprinted loci were examined and compared between different alcoholconsuming groups. In a modest study [61], a trend toward $\mathrm{CpG}$ hypomethylation in moderate to heavy drinkers was observed and reached statistical significance for one differentially methylated region (DMR), but not for another. The effects of alcohol on sperm DNA methylation need further exploration, as do other epigenetic mechanisms, including histone modification and the transmission of RNA species that may affect gene expression in the gametes and early zygote.

It is not surprising that there have been a variety of outcomes in rodent studies exploring paternal preconception effects, as the experimental approaches have differed in design, including dosage (chronic or acute, the latter mimicking binge drinking behavior), administration regime (inhalation, intraperitoneal injection and gavage) and the length of exposure. However, and some exceptions aside, a definite trend is evident with increasing exposure that reflects reduced birth weight in the offspring [62-64], fewer offspring [64,65], and an increased number of malformations [64,66], including dysmorphic craniofacial features and behavioral or cognitive effects [67-70].

Preconception effects in women are more difficult to study as they are invariably influenced by alcoholic behavior that persists into pregnancy and by malnutrition and socioeconomic status $[53,71]$. The effect on female mice exposed chronically for 10 weeks before conception, but not during pregnancy, showed increased transcriptional silencing of the agouti yellow viable allele $\left(A^{v y}\right)$ in the offspring, in a similar trend to those exposed during pregnancy [39]. These effects are indirect because the transcriptional signaling comes from altered methylation of the $A^{v y}$ allele, which was paternally derived in this experimental model. In earlier mouse studies, fetuses and offspring of females exposed only in the preconception period had significantly retarded growth [72-74].

In humans the preimplantation period relates to the first 2 weeks following fertilization, and in mice up to the first 6 days; this is followed by implantation and gastrulation, which is characterized by the formation of the three primary germ layers (mesoderm, ectoderm and endoderm). Some studies have particularly addressed the effects of alcohol during these early stages and have demonstrated that it produces adverse outcomes on the placenta, the fetus, newborn and adult [75,76]. An imprinting mechanism was explored in two recent mouse studies. Preimplantation ethanol exposure resulted in 
decreased placental and fetal weight, and it significantly decreased DNA methylation of the paternal allele of the H19 imprinting control region of the placenta of midgestation embryos, but not the embryos themselves [77]. Using the $A^{v y}$ allele as a reporter gene, gestational exposure during days 1 to 8 after fertilization was shown to result in a significant shift to an increased proportion of pseudoagouti offspring mediated through transcriptional silencing of the agouti locus [39]. Both studies investigated the methylation status of individual loci; the first [77] showed a shift towards hypomethylation and the other [39] to hypermethylation, indicating that there are locus-specific responses to the teratogenic effects of alcohol. Other studies have examined the post-implantation effects of alcohol teratogenesis during a period of rapid cell growth and differentiation, when one would expect extreme sensitivity to environmental insults, as reported in many studies (reviewed in [57]).

The first study to show a direct epigenetic effect of alcohol exposure in the fetus was by Garro et al. [47], in which the authors demonstrated reduced methylase activity and hypomethylation of fetal DNA. A later study [78] showed CpG hypomethylation associated with upregulation of NMDA receptor $2 \mathrm{~B}(N R 2 B)$ gene expression in mouse fetal cortical neurons following chronic ethanol treatment. Many studies have demonstrated that maternal ethanol consumption during fetal development affects mouse and rat offspring, as reflected in phenotypic characteristics such as stunted growth and craniofacial anomalies analogous to the FASD clinical features. Exposure of mouse embryo cell cultures undergoing early neurulation (during the period of gastrulation) demonstrated DNA methylation mediated alterations in gene expression that are proposed to contribute to the FASD phenotype [38].

Transgenerational effects of alcohol (as well as of nutritional supplements and endocrine disrupters) must, of necessity, be mediated through the process of gametogenesis and can be modulated by the maternal environment during pregnancy. There is little evidence to explain the mechanisms involved, but the consequences are beginning to be documented. Studies from a region in northern Sweden, using meticulous birth, medical, lifestyle and mortality records and meteorological and agricultural records reflecting food availability, have demonstrated significant correlations between environmental exposures at critical periods and cross-generational outcomes $[79,80]$. These have been attributed in part to transgenerational epigenetic effects. Nutrition supplementation in pregnant mice is known to shift mouse coat color towards transcriptional silencing of the $A^{v y}$ allele, mediated through DNA methylation, as reflected by an increase in the proportion of pseudoagouti offspring $[81,82]$. In a rat model, exposure of pregnant dams to vinclozolin and methoxychlor (endocrine disruptors) during the period of gonadal sex differentiation in the fetus led to decreased spermatogenic capacity in the male offspring and an increased susceptibility to adult-onset diseases and hypercholesterolemia in the F1 to F4 generations [83,84]. Given that the phenotypic effects of the gestational environmental interventions (nutritional supplementation and exposure to endocrine disruptors) were shown to persist into unexposed subsequent generations, this could be mediated through epigenetic mechanisms.

Further indirect evidence for transgenerational effects, which could lead to an increased prevalence of FASD in communities, come from behavioral and epidemiological studies. Behavioral studies in humans, rats and mice suggest that in utero alcohol exposure may confer increased vulnerability to substance misuse (including alcohol misuse) or addiction in young offspring and adolescents, which sometimes persists into adulthood [85-90]. Studies in South Africa have documented a significant increase in FAS prevalence in a specific community studied at two different times, though not a generation apart. A minimal prevalence of 40.5 per 1,000 was reported in 2000, rising to 65.2 in a report from 2005, using the same diagnostic criteria $[48,91]$.

The studies presented in this section are consistent with the transmission of environmentally acquired changes in epigenetic status, which persist to variable extents in subsequent generations and depend on both the stochastic deposition of epigenetic marks during development and a changing environment.

\section{Implications for prevention and treatment}

FASD results in lifelong disability and there is no cure. The complex molecular basis leading to the development of FASD and the mechanisms that induce the teratogenic effects remain poorly understood. There is compelling evidence that, in addition to the environmental trigger, genetic variation and epigenetic remodeling are important risk factors (Figure 1). There is no safe alcohol dose during pregnancy and, because susceptible genomic attributes in the mothers and their fetuses remain poorly understood, there is no sliding scale that can be administered to reassure pregnant women of their risks. It remains unclear to what extent the damage that occurs during fetal development and growth can be ameliorated through the process of early detection and educational, nutritional and physiological intervention, as has been suggested in some studies $[2,92,93]$. The burden of disease, the high prevalence of FASD and the vulnerability of affected individuals has led to the introduction of protective legislative guidelines in North American countries, but not yet in other parts of the world $[94,95]$. 


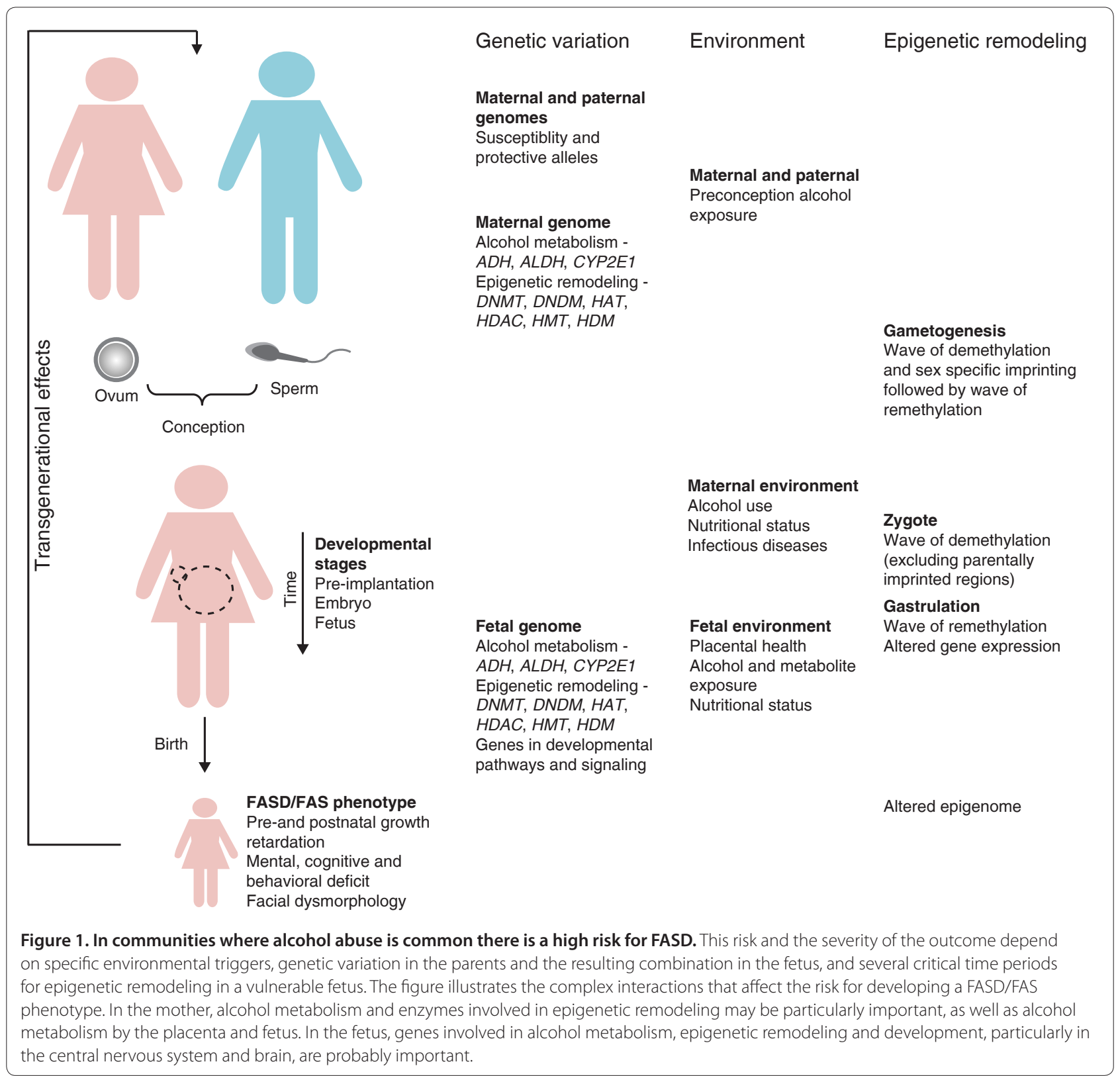

In high-risk communities and individual pregnancies, prevention strategies not only need to target the pregnant mother, but also need to focus on preconception alcohol use in both parents as well as attitudes surrounding a culture of drinking. To develop effective prevention strategies it is important to understand the molecular processes underlying FASD and the physiological and social consequences that lead to excessive alcohol consumption before and after conception. Preventative strategies for FASD will therefore need to include a longterm program, emphasizing abstention during the preconception period as well as during pregnancy, with an understanding that immediate benefits are likely to be subtle but will accrue over subsequent generations. However, in the absence of effective preventative strategies the prevalence of FASD would increase and the burden of disease in future generations would be magnified accordingly.

\section{Abbreviations}

ADH, alcohol dehydrogenase genes; CYP2E1, cytochrome P450 subfamily member 2E1); FAS, fetal alcohol syndrome; FASD, fetal alcohol spectrum disorders.

\section{Competing interests}

The author declares that she has no competing interests.

\section{Acknowledgements}

Grants related to FAS research are gratefully acknowledged and include funding from the March of Dimes (Grant \# 6-FY04-70), the South African National Research Foundation and the NHLS Research Trust. 
Published: 28 April 2010

\section{References}

1. Hoyme HE, May PA, Kalberg WO, Kodituwakku P, Gossage JP, Trujillo PM, Buckley DG, Miller JH, Aragon AS, Khaole N, Viljoen DL, Jones KL, Robinson LK: A practical clinical approach to diagnosis of fetal alcohol spectrum disorders: clarification of the 1996 institute of medicine criteria. Pediatrics 2005, 115:39-47

2. Manning MA, Eugene Hoyme H: Fetal alcohol spectrum disorders: a practical clinical approach to diagnosis. Neurosci Biobehav Rev 2007 31:230-238

3. Stoler JM, Holmes LB: Recognition of facial features of fetal alcohol syndrome in the newborn. Am J Med Genet C Semin Med Genet 2004, 127C:21-27.

4. May PA, Gossage JP: Estimating the prevalence of fetal alcohol syndrome. A summary. Alcohol Res Health 2001, 25:159-167.

5. Viljoen DL, Gossage JP, Brooke L, Adnams CM, Jones KL, Robinson LK, Hoyme HE, Snell C, Khaole NC, Kodituwakku P, Asante KO, Findlay R, Quinton B, Marais AS, Kalberg WO, May PA: Fetal alcohol syndrome epidemiology in a South African community: a second study of a very high prevalence area. J Stud Alcohol 2005, 66:593-604

6. Urban M, Chersich MF, Fourie LA, Chetty C, Olivier L, Vilioen D: Fetal alcohol syndrome among grade 1 schoolchildren in Northern Cape Province: Prevalence and risk factors. S Afr Med J 2008, 98:877-882.

7. WHO: Global Status Report on Alcohol 2004. 2nd edition. Department of Mental Health and Substance Abuse, Geneva: WHO; 2004.

8. Abel EL: An update on incidence of FAS: FAS is not an equal opportunity birth defect. Neurotoxicol Teratol 1995, 17:437-443.

9. Stoler JM, Holmes LB: Under-recognition of prenatal alcohol effects in infants of known alcohol abusing women. J Pediatr 1999, 135:430-436

10. Wattendorf DJ, Muenke M. Fetal alcohol spectrum disorders. Am Fam Physician 2005, 72:279-282, 285

11. Lupton C, Burd L, Harwood R: Cost of fetal alcohol spectrum disorders. Am Med Genet C Semin Med Genet 2004, 127C:42-50.

12. Sampson PD, Streissguth AP, Bookstein FL, Little RE, Clarren SK, Dehaene P, Hanson JW, Graham JM Jr: Incidence of fetal alcohol syndrome and prevalence of alcohol-related neurodevelopmental disorder. Teratology 1997, 56:317-326.

13. Olson HC, Streissguth AP, Sampson PD, Barr HM, Bookstein FL, Thiede K: Association of prenatal alcohol exposure with behavioral and learning problems in early adolescence. J Am Acad Child Adolesc Psychiatry 1997, 36:1187-1194

14. Warner $\mathrm{RH}$, Rosett $\mathrm{HL}$ : The effects of drinking on offspring: an historical survey of the American and British literature. J Stud Alcohol 1975 36:1395-1420

15. Jones KL, Smith DW: Recognition of the fetal alcohol syndrome in early infancy. Lancet 1973, 302:999-1001.

16. Sulik KK, Johnston MC, Daft PA, Russell WE, Dehart DB: Fetal alcohol syndrome and digeorge anomaly: critical ethanol exposure periods for craniofacial malformations as illustrated in an animal model. Am J Med Genet Suppl 1986, 2:97-112

17. Daft PA, Johnston MC, Sulik KK: Abnormal heart and great vessel development following acute ethanol exposure in mice. Teratology 1986, 33:93-104.

18. Downing C, Balderrama-Durbin C, Broncucia H, Gilliam D, Johnson TE: Ethanol teratogenesis in five inbred strains of mice. Alcohol Clin Exp Res 2009, 33:1238-1245

19. Chernoff GF: The fetal alcohol syndrome in mice: maternal variables. Teratology 1980, 22:71-75

20. Gilliam DM, Stilman A, Dudek BC, Riley EP: Fetal alcohol effects in long- and short-sleep mice: activity, passive avoidance, and in utero ethanol levels. Neurotoxicol Teratol 1987, 9:349-357.

21. Goodlett CR, Gilliam DM, Nichols JM, West JR: Genetic influences on brain growth restriction induced by development exposure to alcohol. Neurotoxicology 1989, 10:321-334.

22. Gilliam DM, Kotch LE, Dudek BC, Riley EP: Ethanol teratogenesis in selectivity bred long-sleep and short-sleep mice: a comparison to inbred c57BL/6J mice. Alcohol Clin Exp Res 1989, 13:667-672.

23. Gilliam DM, Irtenkauf KT: Maternal genetic effects on ethanol teratogenesis and dominance of relative embryonic resistance to malformations. Alcohol Clin Exp Res 1990, 14:539-545.
24. Abel EL: Fetal alcohol syndrome in families. Neurotoxicol Teratol 1988, 10:1-2.

25. Streissguth AP, Dehaene P: Fetal alcohol syndrome in twins of alcoholic mothers: concordance of diagnosis and IQ. Am J Med Genet 1993, 47:857-861.

26. Warren KR, LiTK: Genetic polymorphisms: impact on the risk of fetal alcohol spectrum disorders. Birth Defects Res A Clin Mol Teratol 2005, 73:195-203.

27. Gemma S, Vichi S, Testai E: Metabolic and genetic factors contributing to alcohol induced effects and fetal alcohol syndrome. Neurosci Biobehav Rev 2007, 31:221-229

28. Jacobson SW, Carr LG, Croxford J, Sokol RJ, Li TK, Jacobson JL: Protective effects of the alcohol dehydrogenase-ADH1B allele in children exposed to alcohol during pregnancy. J Pediatr 2006, 148:30-37.

29. Arfsten DP, Silbergeld EK, Loffredo CA: Fetal $A D H 2 * 3$, maternal alcohol consumption, and fetal growth. Int J Toxicol 2004, 23:47-54.

30. Viljoen DL, Carr LG, Foroud TM, Brooke L, Ramsay M, Li TK: Alcohol dehydrogenase- $2 * 2$ allele is associated with decreased prevalence of fetal alcohol syndrome in the mixed-ancestry population of the Western Cape province, South Africa. Alcohol Clin Exp Res 2001, 25:1719-1722

31. Green RF, Stoler JM: Alcohol dehydrogenase 1B genotype and fetal alcohol syndrome: a HUGE minireview. Am J Obstet Gynecol 2007, 197:12-25.

32. Zuccolo L, Fitz-Simon N, Gray R, Ring SM, Sayal K, Smith GD, Lewis SJ: A nonsynonymous variant in $A D H 1 B$ is strongly associated with prenatal alcoho use in a European sample of pregnant women. Hum Mol Genet 2009, 18:4457-4466.

33. Shukla SD, Velazquez J, French SW, Lu SC, Ticku MK, Zakhari S: Emerging role of epigenetics in the actions of alcohol. Alcohol Clin Exp Res 2008, 32:1525-1534

34. Guerri C, Bazinet A, Riley EP: Foetal alcohol spectrum disorders and alterations in brain and behaviour. Alcohol Alcohol 2009, 44:108-114.

35. Moonat S, Starkman BG, Sakharkar A, Pandey SC: Neuroscience of alcoholism: molecular and cellular mechanisms. Cell Mol Life Sci 2010, 67:73-88.

36. Sulik KK: Genesis of alcohol-induced craniofacial dysmorphism. Exp Biol Med (Maywood) 2005, 230:366-375.

37. Hard ML, Abdolell M, Robinson BH, Koren G: Gene-expression analysis after alcohol exposure in the developing mouse. J Lab Clin Med 2005, 145:47-54.

38. Liu Y, Balaraman Y, Wang G, Nephew KP, Zhou FC: Alcohol exposure alters DNA methylation profiles in mouse embryos at early neurulation. Epigenetics 2009, 4:500-511.

39. Kaminen-Ahola N, Ahola A, Maga M, Mallitt KA, Fahey P, Cox TC, Whitelaw E, Chong S: Maternal ethanol consumption alters the epigenotype and the phenotype of offspring in a mouse model. PLoS Genet 2010, 6:e1000811.

40. Green ML, Singh AV, Zhang Y, Nemeth KA, Sulik KK, Knudsen TB: Reprogramming of genetic networks during initiation of the fetal alcohol syndrome. Dev Dyn 2007, 236:613-631.

41. Wang G, Wang X, Wang Y, Yang JY, Li L, Nephew KP, Edenberg HJ, Zhou FC, Liu $Y$ : Identification of transcription factor and microRNA binding sites in responsible to fetal alcohol syndrome. BMC Genomics 2008, 9 Suppl 1:S19.

42. Yamada Y, Nagase T, Nagase M, Koshima I: Gene expression changes of sonic hedgehog signaling cascade in a mouse embryonic model of fetal alcohol syndrome. J Craniofac Surg 2005, 16:1055-1061; discussion 1062-1063.

43. Iqbal U, Brien JF, Banjanin S, Andrews MH, Matthews SG, Reynolds JN: Chronic prenatal ethanol exposure alters glucocorticoid signalling in the hippocampus of the postnatal guinea pig. J Neuroendocrinol 2005, 17:600-608.

44. Chen L, Zhang T, Nyomba BL: Insulin resistance of gluconeogenic pathways in neonatal rats after prenatal ethanol exposure. Am J Physiol Regul Integr Comp Physiol 2004, 286:R554-R559.

45. Tsukamoto H, Lu SC: Current concepts in the pathogenesis of alcoholic liver injury. FASEB J 2001, 15:1335-1349

46. Lu SC Mato JM: Role of methionine adenosyltransferase and Sadenosylmethionine in alcohol-associated liver cancer. Alcohol 2005, 35:227-234.

47. Garro AJ, McBeth DL, Lima V, Lieber CS: Ethanol consumption inhibits fetal DNA methylation in mice: implications for the fetal alcohol syndrome. Alcohol Clin Exp Res 1991, 15:395-398.

48. Bielawski DM, Zaher FM, Svinarich DM, Abel EL: Paternal alcohol exposure affects sperm cytosine methyltransferase messenger RNA levels. Alcoho Clin Exp Res 2002, 26:347-351.

49. Pal-Bhadra M, Bhadra U, Jackson DE, Mamatha L, Park PH, Shukla SD. Distinct 
methylation patterns in histone $\mathrm{H} 3$ at Lys-4 and Lys-9 correlate with up- \& down-regulation of genes by ethanol in hepatocytes. Life Sci 2007, 81:979-987

50. Kim JS, Shukla SD: Acute in vivo effect of ethanol (binge drinking) on histone $\mathrm{H} 3$ modifications in rat tissues. Alcohol Alcohol 2006, 41:126-132.

51. Lee YJ, Shukla SD: Histone $\mathrm{H} 3$ phosphorylation at serine 10 and serine 28 is mediated by $\mathrm{p} 38$ MAPK in rat hepatocytes exposed to ethanol and acetaldehyde. Eur J Pharmacol 2007, 573:29-38.

52. Abernon LD: Alcohol: Its Action on the Human Organism. 2nd (Revised) edn. London: His Majesty's Stationery Office; 1923.

53. Haycock PC: Fetal alcohol spectrum disorders: the epigenetic perspective. Biol Reprod 2009, 81:607-617.

54. Reik W, Dean W, Walter J: Epigenetic reprogramming in mammalian development. Science 2001, 293:1089-1093.

55. Estecio MR, Issa JP: Tackling the methylome: recent methodological advances in genome-wide methylation profiling. Genome Med 2009, 1:106.

56. Cudd TA: Animal model systems for the study of alcohol teratology. Exp Biol Med (Maywood) 2005, 230:389-393.

57. Becker HC, Diaz-Granados JL, Randall CL: Teratogenic actions of ethanol in the mouse: a minireview. Pharmacol Biochem Behav 1996, 55:501-513.

58. Stockard CR: The effect on the offspring of intoxicating the male parent and the transmission of the defects to subsequent generations. Am Nat 1913, 47:641-682.

59. Little RE, Sing CF: Father's drinking and infant birth weight: report of an association. Teratology 1987, 36:59-65.

60. Hegedus AM, Alterman Al, Tarter RE: Learning achievement in sons of alcoholics. Alcohol Clin Exp Res 1984, 8:330-333.

61. Ouko LA, Shantikumar K, Knezovich J, Haycock P, Schnugh DJ, Ramsay M: Effect of alcohol consumption on CpG methylation in the differentially methylated regions of $\mathrm{H} 19$ and IG-DMR in male gametes: implications for fetal alcohol spectrum disorders. Alcohol Clin Exp Res 2009, 33:1615-1627.

62. Abel EL, Martier S, Kruger M, Ager J, Sokol RJ: Ratings of fetal alcohol syndrome facial features by medical providers and biomedical scientists. Alcohol Clin Exp Res 1993, 17:717-721.

63. Anderson RA Jr, Furby JE, Oswald C, Zaneveld LJ: Tetratological evaluation of mouse fetuses after paternal alcohol ingestion. Neurobehav Toxicol Teratol 1981, 3:117-120.

64. Mankes RF, LeFevre R, Benitz KF, Rosenblum I, Bates H, Walker Al, Abraham R, Rockwood W: Paternal effects of ethanol in the Long-Evans rat. J Toxicol Environ Health 1982, 10:871-878.

65. Cicero TJ, Nock B, O'Connor LH, Sewing BN, Adams ML, Meyer ER: Acute paternal alcohol exposure impairs fertility and fetal outcome. Life Sci 1994, 55:PL33-PL36.

66. Bielawski DM, Abel EL: Acute treatment of paternal alcohol exposure produces malformations in offspring. Alcohol 1997, 14:397-401.

67. Abel EL, Bilitzke P: Paternal alcohol exposure: paradoxical effect in mice and rats. Psychopharmacology (Berl) 1990, 100:159-164.

68. Abel EL, Berman RF: Long-term behavioral effects of prenatal alcohol exposure in rats. Neurotoxicol Teratol 1994, 16:467-470.

69. Abel EL, Lee JA: Paternal alcohol exposure affects offspring behavior but not body or organ weights in mice. Alcohol Clin Exp Res 1988, 12:349-355.

70. Abel EL, Tan SE: Effects of paternal alcohol consumption on pregnancy outcome in rats. Neurotoxicol Teratol 1988, 10:187-192.

71. Viljoen D, Croxford J, Gossage JP, Kodituwakku PW, May PA: Characteristics of mothers of children with fetal alcohol syndrome in the Western Cape Province of South Africa: a case control study. J Stud Alcohol 2002, 63:6-17.

72. Little RE, Streissguth AP, Barr HM, Herman CS: Decreased birth weight in infants of alcoholic women who abstained during pregnancy. J Pediatr 1980, 96:974-977.

73. Livy DJ, Maier SE, West JR: Long-term alcohol exposure prior to conception results in lower fetal body weights. Birth Defects Res B Dev Reprod Toxicol 2004, 71:135-141.

74. Becker HC, Randall CL: Two generations of maternal alcohol consumption in mice: effect on pregnancy outcome. Alcohol Clin Exp Res 1987, 11:240-242.

75. Padmanabhan R, Hameed MS: Effects of acute doses of ethanol administered at pre-implantation stages on fetal development in the mouse. Drug Alcohol Depend 1988, 22:91-100.
76. Checiu M, Sandor S: The effect of ethanol upon early development in mice and rats. IX. Late effect of acute preimplantation intoxication in mice. Morphol Embryol (Bucur) 1986, 32:5-11.

77. Haycock PC, Ramsay M: Exposure of mouse embryos to ethanol during preimplantation development: effect on DNA methylation in the $\mathrm{H} 19$ imprinting control region. Biol Reprod 2009, 81:618-627.

78. Marutha Ravindran CR, Ticku MK: Changes in methylation pattern of NMDA receptor NR2B gene in cortical neurons after chronic ethanol treatment in mice. Brain Res Mol Brain Res 2004, 121:19-27.

79. Bygren $L O$, Kaati $G$, Edvinsson S: Longevity determined by paternal ancestors' nutrition during their slow growth period. Acta Biotheor 2001, 49:53-59.

80. Pembrey ME, Bygren LO, Kaati G, Edvinsson S, Northstone K, Sjostrom M, Golding J: Sex-specific, male-line transgenerational responses in humans. Eur J Hum Genet 2006, 14:159-166.

81. Cooney CA, Dave AA, Wolff GL: Maternal methyl supplements in mice affect epigenetic variation and DNA methylation of offspring. J Nutr 2002, 132:2393S-2400S.

82. Cropley JE, Suter CM, Beckman KB, Martin DI: Germ-line epigenetic modification of the murine $A^{\text {vy }}$ allele by nutritional supplementation. Proc Natl Acad Sci USA 2006, 103:17308-17312.

83. Anway MD, Cupp AS, Uzumcu M, Skinner MK: Epigenetic transgenerational actions of endocrine disruptors and male fertility. Science 2005 308:1466-1469.

84. Anway MD, Leathers C, Skinner MK: Endocrine disruptor vinclozolin induced epigenetic transgenerational adult-onset disease. Endocrinology 2006, 147:5515-5523.

85. Randall CL, Hughes SS, Williams CK, Anton RF: Effect of prenatal alcohol exposure on consumption of alcohol and alcohol-induced sleep time in mice. Pharmacol Biochem Behav 1983, 18 Suppl 1:325-329.

86. Coles CD, Smith IE, Falek A: Prenatal alcohol exposure and infant behavior: immediate effects and implications for later development. Adv Alcohol Subst Abuse 1987, 6:87-104.

87. Barbier E, Pierrefiche O, Vaudry D, Vaudry H, Daoust M, Naassila M: Long-term alterations in vulnerability to addiction to drugs of abuse and in brain gene expression after early life ethanol exposure. Neuropharmacology 2008, 55:1199-1211.

88. Middleton FA, Carrierfenster K, Mooney SM, Youngentob SL: Gestational ethanol exposure alters the behavioral response to ethanol odor and the expression of neurotransmission genes in the olfactory bulb of adolescent rats. Brain Res 2009, 1252:105-116.

89. Chotro MG, Arias C, Laviola G: Increased ethanol intake after prenatal ethanol exposure: studies with animals. Neurosci Biobehav Rev 2007, 31:181-191.

90. Hill SY, Lowers L, Locke-Wellman J, Shen SA: Maternal smoking and drinking during pregnancy and the risk for child and adolescent psychiatric disorders. J Stud Alcohol 2000, 61:661-668.

91. May PA, Brooke L, Gossage JP, Croxford J, Adnams C, Jones KL, Robinson L, Viljoen D: Epidemiology of fetal alcohol syndrome in a South African community in the Western Cape Province. Am J Public Health 2000, 90:1905-1912.

92. Gabriel Kl, Glavas MM, Ellis L, Weinberg J: Postnatal handling does not normalize hypothalamic corticotropin-releasing factor mRNA levels in animals prenatally exposed to ethanol. Brain Res Dev Brain Res 2005, 157:74-82

93. Kelly SJ, Goodlett CR, Hannigan JH: Animal models of fetal alcohol spectrum disorders: impact of the social environment. Dev Disabil Res Rev 2009, 15:200-208.

94. Fast DK, Conry J: Fetal alcohol spectrum disorders and the criminal justice system. Dev Disabil Res Rev 2009, 15:250-257.

95. Lupton ML: Is the foetal alcohol syndrome child protected by South African law? Med Law 1994, 13:79-94.

\section{doi:10.1186/gm148}

Cite this article as: Ramsay M: Genetic and epigenetic insights into fetal alcohol spectrum disorders. Genome Medicine 2010, 2:27. 